\title{
The Digital University: Of March Hares and Tortoises
}

\section{Ashwin Desai \\ ORCID iD: https://orcid.org/0000-0003-4091-7449}

\author{
'Why did you call him Tortoise, if he wasn't one?' Alice \\ asked. \\ 'We called him Tortoise because he taught us'. \\ (Lewis Carroll, Alice in Wonderland).
}

\section{Abstract}

The learning environment of universities is changing dramatically with the coming of COVID-19. Universities were summarily evacuated and plans put in place to ensure online teaching. In some senses, this was the quickening of a trend that was already unfolding, while for others it signaled new territory. This article explores the coming of online education by highlighting the experiences of lecturers who have already taught courses, while raising questions about disciplinary boundaries and knowledge production. It situates this discussion by exploring the challenges to the traditional notions of the role of universities, and the changing orientations of the academy, against the backdrop of the global juggernaut of privatised higher education.

Keywords: Online learning, knowledge, big data, COVID-19

\section{The Coming of the Wicked}

That is the path of wickedness

Tho some call it the road to heaven ...

(Rhymer quoted in Nicholl 1997:17).

The onset of COVID-19 brought to the fore the contrast which Brown, Harris, 
and Russell make between 'wicked problems' and 'tame problems'. The latter can be solved with existing modes of inquiry and decision-making. A wicked problem is a complex issue that defies complete definition, for which there can be no final solution, since any resolution generates further issues, and where solutions are not true or false or good or bad, but the best that can be done at the time (Brown, Harris \& Russell 2010: 4). Building on this idea, Bunders, Bunders, and Zweekhorst introduce the idea of super-wicked problems in which:

time is running out to find and test solutions .... There is no central authority .... Those seeking to solve the problem are also causing it ... vested interests ... hamper an adequate response and the finding of new options .... humans show a preference for an immediate reward, even if the reward that comes later has much more value .... Thus, not only are partial solutions that work immediately favoured over more structural solutions, but public opinion is also likely to change in favour of the quick fix as time progresses (2015: 23).

In the unfolding crisis of COVID-19, we witness the symptoms of wicked problems with the rush to produce a vaccine, the competing for resources by nation-states, the attempted delegitimisation of the World Health Organisation (WHO) and the quick-fix of lockdowns. In a somewhat similar vein, Laszlo writes that:

in a condition of chaos, the slightest modification can expand and change the dynamics of the whole system. This is not necessarily a negative factor: there are many instances of chaos, and some of them are highly creative .... Chaos harbours danger as well as promise .... Society ... enters a chaotic state from time to time. This is not a state of anarchy but of ultrasensitivity - the prelude to change. In a chaotic condition, society is sensitive to every small fluctuation, to every new idea, new movement, new way of thinking and acting .... in conditions of turbulence and turmoil people are willing to consider alternatives which during a more stable period would have been very likely dismissed (2005: 59-61).

Is it a time of 'danger' or 'promise'? Are people simply wanting to get 
back to the way things were or 'consider alternatives', and if so, what are those alternatives?

In trying to understand the longer-term impact of COVID-19 on universities, it is difficult to make predictions or to plot policies, in what Thompson and Beck describe as a conjuncture of 'decision-making under conditions of contradictory certainties' (cited in Urry 2016: 153). But, in pivotal moments, there are possibilities of hurrying change that was slowly coming into being. Against this background of 'wicked problems', this article, rather than putting a raft of policy formulations forward, raises a myriad of issues to consider in thinking about the future of universities.

\section{The Closing and Opening}

And just as astonishing is the knowledge

That we are, more or less,

The makers of the future.

We create what time will frame.

And a beautiful dream shaped

And realised by a beautiful mind,

Is one of the greatest gifts

We can make our fellow beings (Okri 1999: 56).

On April 30 2020, Minister of Higher Education, Training, Science and Innovation Blade Nzimande, announced that it was

... decided not to resume with campus-based academic activity throughout the PSET sector, including all Universities and TVET Colleges, both public and private, during the Level Four (4) lockdown period.

He suggested that efforts would be made in,

Developing and implementing effective multi-modal remote learning systems (digital, analogue and physical delivery of learning materials) to provide a reasonable level of academic support to all our students at all institutions to resume academic learning and teaching support. As 
we are in an unprecedented emergency, we have to use all available tools to reach our students fully cognisant that it will not substitute the need for contact learning when conditions permit. This we will do making sure that No student or institution is left behind (Nzimande 2020).

The details as to how the Minister would ensure that 'No student or institution is left behind' were hazy and raised several questions. How would students, who had been asked to leave their university residences and return to deep rural areas for the duration of the lockdown, be able to access online classes? What about those who did not have access to laptops? Would the quick-fire transition to online deepen the uneven development of higher education institutions?

These were among the issues raised by a group of academics from across the country, who echoed these sentiments when they called for a Social Pedagogy for Pandemic Covid19, which:

- Must allow for students to be active citizens and engage in a socially responsive way. This requires us to adjust our teaching based on unfolding experiences within the context of a pandemic in a manner that links teaching and learning with communities, within the global context.

- This entails building on the education for liberation trajectories of people's equal education and the free education conceptualisations generated from the \#FeesMustFall momentum.

- Preparation for this pedagogy will involve a programme of dialogue, resourcing, and development engaging teachers, students, and our respective social, economic, and political environments as well as state and institutional partners.

- This consultative process allows teachers and students to continuously develop and review methods as the process unfolds.

- Assessment before returning to campus or school-based teaching must be formative to contribute to a programme of just recovery. Further formative and summative assessments after return to campuses and schools will ensure academic integrity and fair progression.

It was a shopping list that, like Dr. Nzimande's statement, raised more ques- 
tions than answers. Details, such as the time-frame for dialogue, what would constitute a 'just recovery' or be 'socially responsive', what would be the litmus test for meaningful dialogue to take place, for how long, and given that the poor do not have access to the internet, how will they participate, were, like the Minister's announcement, scanty in detail. One virtue is that the intervention put on the table, these pertinent issues. But, these questions were largely ignored as universities hastened online to 'save' the academic year. Academics soon became consumed in the technical aspects of such a move, and those who asked searching questions about the impact on the future of universities and knowledge production were seen as nay-sayers, Luddites even.

\section{Student and Staff Experience}

Have all thoughts, possibilities, ideas,

Philosophies been exhausted?

(Okri 1999: 27).

What were the immediate reactions of students? Siya Shazi, a student of Information Systems at UKZN, related his experiences of online learning in the Daily Vox:

The online learning programme started at UKZN just after the lockdown began at the end of March. With UKZN specifically, there really has been challenges with data. They gave us $500 \mathrm{mb}$ only for us to find out that this is limited to certain specific sites .... I have to use data to download articles online, to go into YouTube to watch a video so that I can have enough information that will help me in order to be ready to write something that is conducive for an academic paper .... The psychological impact of it has really not been discussed. It's affecting me ... we are behind in terms of ensuring that everyone has a laptop and Wifi and free data wherever they are .... There is a lack of leadership and coming together to ensure that there is a solidarity fund where there will be funds for people who are being affected by the pandemic. It has been difficult for me personally due to limited data and not being funded. I had to move out from res where there was wifi. After that having to get WiFi was a serious challenge .... Even 
though it wasn't allowed to move around, when I would go to the shop I would go with my phone to download as many articles as possible so that I wouldn't use as much data to download .... There are many students behind in learning and work. They've always seen a teacher or lecturer in front of them or someone to study with but due to this, they are alone. I think that's where the biggest challenge is. This is the time for people to love one another and reach out and ask if you are coping .... I think that's where we are lacking as well. We are lacking in resources but also lacking in reaching out to others (Moosa 2020).

Shazi was raising challenges in the most considered and moving of ways. Many universities scrambled to address these issues across campuses. Some managements were more agile than others, while Minister Nzimande was mostly silent, after his promise that no student would be left behind. Universities were left to their own devices, both literally and figuratively. Meanwhile, at many universities, online learning was travelling with the speed of a March Hare. Hard-shelled academics, used to the steady-as-you-go pace of the classroom, incrementally sprinkling a few new tricks like power-point presentations, have had to poke out their heads (suitably masked) and respond to the online pandemic. One of the earliest to go online was the University of Johannesburg. I was keen to get immediate impressions and views from those who had gone online. As soon as I became aware that one of my colleagues had just completed teaching a class of 879 first year students, I sent him a set of exploratory questions:

- What was your experience of moving to online teaching from the onset of lockdown?

Initially, the experience was quite daunting to me because I was not conversant with teaching online and had never used Blackboard's new set-up. However, after going through a quick crash-course on how the Blackboard works, I began to slowly grow in confidence using the Blackboard forum for online teaching, until I became quite savvy in using the platform.

The experience also seemed surreal at times because I have been teaching face-to-face for seven years and so the sudden shift to online teaching seemed weird because I was not standing in front of the students and engaging with them on a one-to-one basis. I was very much worried about whether the students would be able to understand the lecture material which was being dis- 
seminated through podcasts and lecture slides.

I encouraged the students to ask others via the Discussion Forum which I created, however, it never proved to be the same as engaging students on a face-to-face basis as I was accustomed to.

Assessments were initially nerve-wracking for me because I was worried, at least initially, whether most students had access to computers and data, and also about their performance since they were learning virtually for the very first time. However, once it was established that most students had access to computers and data and that they were performing decently, even though they were not being challenged critically in their assessments (barring the exam), I then calmed down.

- What forms of testing did you use, if any?

The students were assessed via mostly true/false quizzes, a test that had a short answer (5 Mark) questions, medium-range (15 Mark) questions and an exam, which was constituted of two essay questions, which required them to apply learned concepts and theories to the South African context. The efficacy of the true/false quizzes was questioned by some colleagues because of their nature of most probably promoting binary thinking among the First Year students in a discipline such as Sociology, which is supposed to encourage critical thinking, and which accounts for the plethora of realities that confront us in our daily lived realities. The criticism was fair, however, there was a method in the madness of assessing the students through true/false quizzes. Firstly, the idea was meant to assess students in a quick and light fashion that would require them to know the module's material without having to spend much time on Blackboard, and in the process, use a lot of their precious data on one module. Secondly, the idea was to ensure that students knew the basic concepts around the First Year module without having to initially go deep into problematising these concepts and theories. Such an exercise was partly reserved for the Test and then the exam.

- What was class attendance like?

Every week, an average of 750 out of the 879 registered students were able to engage with the lecture material that was posted weekly on the Blackboard.

- What were the pros, if any?

The pros were that learning was able to continue because most students have 
paid their tuition fees for 2020. Being introduced to online teaching, even though it meant being thrown into the deep end without any warning for both staff and students will serve both parties well moving forward, because online teaching appears to be the future of teaching and learning, given the messages of the university, before the lockdown, on the basis that online teaching is compatible with the Fourth Industrial Revolution, which the university leadership has been championing.

- What were the cons, if any?

Online teaching is very demanding, especially when it comes to teaching huge undergraduate classes. As the lecturer, you are always kept on your toes because students will e-mail you at any given time, unlike during face-to-face teaching and learning, where students would normally consult during set days and times during the week. Due to the unpredictable nature of technology, when it comes to assessments, you will be kept busy the whole time, entertaining students' queries and fears during assessment submission days, and this might entail not sleeping at times, for you to cater and respond to students expeditiously, who will be e-mailing in panic over one problem or another. Thus, managing online assessments with huge undergraduate classes is both physically and emotionally draining. It really saps your energy.

- How did it impact on you?

I have mixed feelings. It was my first time teaching virtually, for the whole Term and the experience proved to be quite draining. However, the fact that most of the students gave it their whole (came to the party in terms of engaging with the module), managed to temper and somewhat overshadow the challenges of online teaching and learning.

- What do you see as the future of teaching?

After this lockdown, I am increasingly seeing virtual teaching and learning being the future in most SA universities.

A lecturer who taught a third-year class of just over 200 students also related her experiences:

- What was class attendance like?

No 'attendance' per se - I developed the module so that they can access the 'classes' at any time and multiple times. Posting weekly PowerPoint slides 
with my voice speaking through each slide; additional readings and/or YouTube videos; and checklists in preparation for their assignments/proposals. I did, however, track the number of views on Blackboard, and the majority of students accessed them.

\section{- What were the pros if any?}

From informal student feedback, as well as feedback from the third-year tutor, it was evident that students liked the approach I took and the material I posted. The marks also show that they did well - which I take as a win. I learned a lot, in terms of the culture of teaching and how that needs to change during these times - so I hope I can incorporate this in my future teachings.

- What were the cons if any?

I missed the face-to-face interaction. I did have the odd Zoom session (for consultation) to try and connect with students, but only about 40 out of 217 attended. The cons mostly had to do with the administrative strains that came with the lockdown. Some students could not access Blackboard or upload assignments due to bad internet connectivity. I had to find ways to accommodate all of them (my motto: leave NO student behind!), which often meant me teaching over the phone to them at strange hours of the day and night (when they had 'better' connectivity or using a friend or family member's phone-I did four 1 am sessions), or over weekends, or communicating lectures via WhatsApp. Luckily it all worked out, it just meant extra time spent and going the extra distance during my time. Some students wrote to me in utter panic and I had to constantly reassure them that things will be okay - this went beyond classwork and into their emotional wellbeing as well. This happened a lot. So, I was constantly consulting students around the 'new normal' and how they can manage their challenges.

\section{- How did it impact on you?}

Dealing with student queries that go way beyond just coursework takes an emotional toll. I am the type of lecturer who aims to give my all to my students, and their serious issues haunt me. The boundaries between teacher and student have been blurred and cannot be ignored by our institution. My work-life spillover has been complicated. It sounds silly, but the number of emails was just an administrative nightmare and I feel close to burn out. 
The new learning environment, at least at one university, has taken off relatively smoothly. The direct classroom experience has not meant students are dealt with remotely. Many have used technology as a way to communicate directly with lecturers, cutting down distance. At the same time, lecturers have found that there is no limit to 'office hours' and they have to double as both therapist and teacher. The psychological services of the university were widely used, and one wonders how these services will function in the context of online learning.

Overall, one gets a real sense that at UJ, lecturers hit the ground running. The take-up rate from students was incredibly high. But there was a toll taken on lecturers. Despite the 'distance', it appears that students entered the lives of lecturers in much more persistent, time-consuming and intrusive ways.

Meanwhile, it was noteworthy that lecturers got on with things, determined that the year would not be lost as innovations were made, like accessing lectures at any time and tests in terms of quizzes that eased students into a new way of learning.

As the date of students being allowed back to university was pushed back and warnings issued that the danger of the virus was ongoing, universities have begun to think about changes in their ways of working in the longer-term, central to which is online learning.

\section{The (Twin) Towers of Learning?}

'I couldn't afford to learn it', said the Mock Turtle with a sigh.

'I only took the regular course'. 'What was that?' inquired Alice'. Reeling and Writhing, of course, to begin with', the Mock Turtle replied; 'and then the different branches of Arithmetic - Ambition, Distraction, Uglification, and Derision' (Lewis Carroll, Alice in Wonderland).

The move to online learning, done with the speed of Achilles, has the potential to change the notion of the university in fundamental ways.

The philosopher Agamben argues that the turn to online goes beyond the diminution of life experience and ways of seeing, given the dominance of the computer screen: 
Much more decisive is what is taking place is something that, significantly, is not spoken of at all: namely, the end of being a student ... as a form of life .... To be a student entailed, first of all, a form of life in which studying and listening to lectures were certainly decisive features, but no less important were encounters and constant exchanges with other scholarii .... This form of life evolved in various ways over the centuries, but, from the clerici vagantes of the Middle Ages to the student movements of the twentieth century, the social dimension of the phenomenon remained constant. Anyone who has taught in a university classroom knows well how, in front of one's very eyes, friendships are made, and, according to their cultural and political interests, small study and research groups are formed that continue even after classes have ended. All this, which has lasted for almost ten centuries, now ends forever. Students will no longer live in the cities where their universities are located. Instead, they will listen to lectures closed up in their rooms and sometimes separated by hundreds of kilometres from those who were formerly their classmates. Small cities that were once prestigious university towns will see their communities of students, who frequently made up the most lively part, disappear from their streets (Agamben 2020).

While Agamben might be accused of romanticising universities, he goes on to concede that universities had grown complacent and that their place as vanguard of knowledge production and dissemination were eroding:

About every social phenomenon that dies it can be said that, in a certain sense, it deserved its end; it is certain that our universities reached such a degree of corruption and specialist ignorance that it isn't possible to mourn them, and the form of life of students, consequently, has been equally impoverished.

Chunks of the academy have long quarantined themselves from experiences outside the laager, living in the world of texts and textbooks. A point Geoff Dyer makes eloquently:

That is the hallmark of academic criticism: it kills everything it touches. Walk around a university campus and there is an almost 
palpable smell of death about the place because hundreds of academics are busy killing everything they touch. I recently met an academic who said he taught German literature. I was aghast: to think, this man who had been in universities all his life was teaching Rilke....You don't teach Rilke I wanted to say...Y You turn him into dust and then you go off to conferences where dozens of other academic-morticians gather with the express intention of killing Rilke and turning him into dust .... how can you know anything about literature if all you've done is read books? (1997: 101).

The 'deconstructivist' method that is all the rage at universities was exposed in 2018 when it was revealed that three researchers in the United States had stage-managed a hoax by publishing fake research in respected journals. Their intention was to expose ideological bias and a lack of careful reviewing oversight. Of the 20 articles submitted, 7 were accepted after review processes. One of the articles, 'Human Reaction to Rape Culture and Queer Performativity at Urban Dog Parks in Portland, Oregon' sought to inquire; 'Do dogs suffer oppression based upon (perceived) gender?' Another of the articles which passed peer review made the case that a man masturbating while thinking of a woman without her consent is committing sexual assault. Entitled 'Rubbing One Out: Defining Metasexual Violence of Objectification Through Nonconsensual Masturbation'. It set out its thesis:

By drawing upon empirical studies of psychological harms of objectification, especially through depersonalization, and exploring several veins of theoretical literature on nonphysical forms of sexual violence, this article seeks to situate non-consensual male autoerotic fantasizing about women as a form of metasexual violence that depersonalises her, injures her being on an affective level, contributes to consequent harms of objectification and rape culture, and can appropriate her identity for the purpose of male sexual gratification (cited in Mounk 2018).

The scam had echoes of an earlier hoax by psychist Alan Sokal, that published what he himself considered a load of nonsense in the journal Social Text: 
Early in 1994, Sokal set himself to writing an article full of what he saw as the worst sins of cultural studies and science studies: appeals to authority rather than logic to support arguments, unreadable prose, mistaken claims about scientific theories, and a general failure to give the scientific method its due. But he had to do his work carefully. The article had to be 'bad' enough to make his point - but 'good' enough to find a perch from which to make it .... Unlike most scholars, however, Sokal was searching for references that struck him as nonsensical. He gathered a collection of the best (or worst) he could find and built an impenetrable essay around them. The result: a mix of plausible claims that go too far, implausible claims that go nowhere at all (concealed in syntax so dense as to be almost unreadable), and fringe philosophical theories set forth as widely accepted scientific advances. He topped these off with a vast number of endnotes and the occasional truth, and christened the piece 'Transgressing the Boundaries: Toward a Transformative Hermeneutics of Quantum Gravity' (Lingua Franca 2000: 3).

The publication of these articles, some in what is referred to as high impact journals, raises deep questions about the whole process of peer review and the faddishness of academic life, but also how the drive to publish in particular journals that demand an arcane and jargonised style isolates the academy from the public domain. The nature and form of the performance evaluation system for academics often serves to reinforce these tendencies. The emphasis is to concentrate on a narrow area of one discipline, defending your turf like any worthy drug lord, and resulting in what Mills-Wright called 'the lazy safety of specialization' (Mills-Wright 1959/2000: 21).

At places like the University of Johannesburg, there have been real attempts to value interventions in the media by academics, with COVID-19 being an example of this, as staff made a series of interventions that were widely read. It is of course also the moment of 'wicked problems' that the possibility of fame and funding can open the door to fraud. The most significant and potentially damaging case of quick-fire, unverified research arose when a number of scientists began to question the findings in a number of papers published in high level medical journals, including Lancet and the New England Journal of Medicine, by a small US analytics company called Surgisphere, with just 11 employees. After more probing, it was discovered 
that the research was based on an analysis of health records from patients on six continents, including Africa, where there were hardly any patients at the time, and where it was unlikely that records would be linked to an international health database (Davey 2020). Nothwithstanding, Universities are still places in which independent, rigorous research can be conducted. However, the temptation to quantify academic output, follow the money and erode ethical boundaries needs to be resisted. At the core of our work surely are those traditional pillars; methodological meticulousness and interpretive imagination.

Meanwhile, one of the ironies of South African society is that, as we have massified tertiary education, we have also seen record levels of unemployment. It brings back haunting memories of a book I read in the 1980s, entitled The Overeducated American by Richard Freeman. These are difficult issues to raise, as students, many first-generation, see university as a way to achieve class mobility. One of the consequences is that upon leaving university with degree in hand, they may have to take jobs as salespersons for example, which push those without credentials further downwards. Gary Roth, author of The Educated Underclass: Students and the Promise of Social Mobility (2019), has in many ways updated Freeman's book and shows how those with degrees hardly ever find jobs that match their field of study. Still, we live in an age obsessed with certification, and as COVID-19 smashes the economy and 4IR makes more and more occupations redundant, the form and content of a university degree has come under increased scrutiny. Some, such as Curtis Bonk, have welcomed the development and spread of online education as helping to flatten the world. He argues that:

Web technology offers new hope for educating the citizens of this planet. It is the opening up of education that ultimately makes a flatter or more robust economic world possible. In the twenty-first century, education trumps the economy as the key card to participation in the world ... (Bonk 2009: 7-8; 39).

But this notion of the flat world does not bear up to everyday experience. Education is not necessarily the key to participation in the economy. Pandemics, and the uncertainty they generate, only serve to increase managerial power, as supply chains and changes in market needs mean faster decision-making at the top. Most will have poor if limited Wi-Fi, and cramped living space, while the personal interactions and networks of sharing are 
eroded. The best lecturers are those who can present glossy, easy to digest power-point presentations.

On the other side, the value of online learning is that it allows the university, often harder to turn than the Titanic, to be nimbler, to throw its cabins open to more and more people. Students can spend a month at university, then be able to learn from home and return for another few weeks. This would allow for multiple entry and exit points and create the conditions for accessible lifelong learning. A once-off three or four-year degree as a way of thinking about education that is standardised into layers of knowledge, or what Ivan Illich called 'prefabricated blocks' (1973: 25), is an anachronism. Despite the supposed opening up of the system, adult learning is largely on the decline, with many opting for unregulated short courses that give a certificate in the end. The flexibility offered by online learning allows people to keep returning, making lifelong learning, re-skilling, and upgrading a real possibility. Online students can enjoy the flexibility of accessing knowledge at different times and go back to lectures they find interesting or challenging.

There is the danger though, that these limited duration activities are separated from each other. What Rosa calls 'episodes of experience' are supplanting 'experiences which leave a mark, which connect to, or are relevant for, our identity and history; experiences which touch or change who we are' (Rosa 2010: 94-95).

And, what will the impact of limited duration activities have on creativity and innovation?

Simply having a computer and expecting students to get on with it occludes the problems which students have with learning, the personal troubles that beset them. And, there is the danger of solitude; the classroom gives you interactions, debate, a chance to cross swords with your peers. As Joseph Viner put it, the 'nonsense people can come to believe if they think alone' (cited in Baum \& McPherson 2019: 246). The danger may be however, that feedback is reduced so dramatically that there can be an overall detachment.

One has to guard against "not so much the use of technology in the service of education as the usurpation of education in the service of technological enterprise' (Noble 1998: 267). There are questions which COVID-19 raises that strike at the heart of research and knowledge. What does traditional field-work mean in the age of the pandemic? Are methodologies like participant-observation and life-histories over and will we witness a turn to Big Data? As Mayer-Schonberger and Cukier point out: 
In the age of small data, we were driven by hypotheses about how the world worked, which we then attempted to validate by collecting and analysing data. In the future, our understanding will be driven more by the abundance of data rather than by hypotheses (2013: 6869).

But, as Sardar points out, an uncritical reliance on Big Data is fraught with danger:

Big Data does not differentiate between facts and 'alternative facts', truth or lies, knowledge or bullshit, news or fake news, politics or conspiracy theories, legitimate concerns of dissidents or the paranoia of anonymous on-line mobs, genuine comedy or racism, and bigotry masquerading as 'earthy humour', irony and sarcasm. All is shovelled up. As such, Big Data is a repository for plain ignorance: blatant lies, obvious bullshit, and all the dark paraphernalia we find on social media, on-line platforms and other digital apparatus .... It is essentially a postnormal phenomenon. The main drivers of postnormal times - the 4 S's - are clearly exhibited by Big Data: Speed (it is instantaneous), Scope (it is global), Scale (it reaches not just the individual level but also extracts the very essence of what makes an individual truly unique); and Simultaneity (it works simultaneously across all aspect of human and planetary life). As such, Big Data ... accumulates widely diverging truths, falsehoods, behaviours, orientations, ideologies, and worldviews (2020: 6).

This danger is accompanied by the question of who owns Big Data? As Harari notes:

Big Data algorithms might create digital dictatorships in which all power is concentrated in the hands of a tiny elite while most people suffer not from exploitation, but from something far worse irrelevance (Harari 2018: 19).

One of the major changes to the university, with the push to digitisation, is the eroding of student experience. Universities have just come through the Fees Must Fall struggle - that was a major victory. It spurred 


\section{Ashwin Desai}

battles around decolonising the curriculum, with seminars and classrooms witnessing serious debates, ranging from sexuality, racism, and the economy. Many of the political parties' backbenches cut their teeth in student organisations. With the evacuation of students from the university, this incubator has been and will be removed, as will the major force challenging managerialism of universities and the insularity of academics. Alongside this, what does the move to digital mean for what we regard as knowledge? What impact does this have on decolonising the curriculum, which was the drive through 2018-2019? In this debate, suprisingly little attention has been paid to the deolonising/independence period of the 60s in Africa. How did African universities respond and what lessons can we learn from it? (for an excellent review article, see Christopher Clapham 2020).

How will students organise? Will there be different ways to exert pressure and resist policies of management and universities that move beyond the mass? Many a Vice-Chancellor might breathe a sigh of relief to have the student mass off-line as it were. However, there will be new forms of activism, as the digital university is always open to viral attacks that can paralyse an institution in ways that students in mass (they are often a minority anyways) can only dream of.

There are other dangers too lurking for local universities, with the arrival of what is referred to as Massive Online Open Courses (MOOC's). Ivancheva and Swartz (2020) have shown how online programme management providers (OPMs), shorthand for companies that provide services for online higher education, have become big business.

In their article, they reveal that:

Senior managers from UK and South African public universities are tempted to, and increasingly do, partner with OPMs. The business model for the OPMs is simple: for up to $50-70 \%$ of revenue from shared online courses or degrees, and for access to huge amounts of student data, OPMs offer as little as some start-up capital and services like marketing, recruitment, and digital platforms - all assets and functions which most universities already have in-house or through subcontractors.

This must be viewed alongside the rise of an Emerging Global Model (EGM) in recent times. These organisations, 
represent the leading edge of higher education's embrace of the forces of globalism. [They] are characterised by an intensity of research that far exceeds past experience. They are engaged in worldwide competetion for students, faculty, staff, and funding; they operate in an environment in which traditional political, linguistic, and access boundaries are increasingly porous. These top universities look beyond the boundaries of their countries in which they are located to define their scope as trans-national in nature (Mohrman, Ma \& Baker 2008: 6).

MOOC's lend themselves to a 'notion of knowledge ... quite close to the notion of information ... set of facts, pieces of data, or concrete bits of a larger process' (Rhoads, Berdan \& Toven-Lindsey 2013: 92).

Online also raises the issue of universities with 'big' reputations dominating the market. Why not take a degree from Harvard rather than UJ? Already, Harvard has half-a-million students registered online. They can pay celebrity academics to do podcasts and use this to attract students. Let's be serious, my students would prefer a lecture from Cornel West than me; a degree from Yale than from MUT (Mangosuthu University of Technology). As Jonathan Rees points to, the onset of super-professors reinforces,

the class differences that MOOCs created between different strata of faculty. How could mere mortals compete against the best teachers at the best universities piped into living rooms around the world, teaching MOOCs that covered all the subjects that people everywhere craved to learn? But what happens to the professors who get left behind? As online classes got scaled up, the thinking went, and MOOCs get scaled-down, all the rest of us would be left as ministers without portfolios (2016).

There is a danger that we will flatten out students and global experiences. But, we bring our histories to the classroom. COVID-19 has brought home how the notion of some pure science delinked from the social is fraught with dangers. While university professors are still engaged in trench warfare, policing the border of their disciplines, and grudgingly conceding some form of inter-disciplinarity, the world as Laszlo shows, has pushed ahead:

The demands on scientists are great, and they are distributed through- 
out the social and the natural sciences. These are not problems for the sociologist or the political scientist alone. They are also problems for the ecologist, the urbanist, the psychologist, the demographer, the economist, the chemist and the physicist - and for the cybernetician and systems scientist. Within the current boundaries of the disciplines, no scientist is able to successfully confront them. The scientific establishment was traditionally reluctant to undertake such interdisciplinary projects to apply science to human problems This, however, is changing. Disciplinary boundaries are not eternal (2005: 89).

Ngugi's plea of not remaining 'cocooned in our libraries and scholarly disciplines, muttering to ourselves: I am only a surgeon; I am a scientist; I am an economist; or I am simply a critic, a teacher, a lecturer' but rather 'turn the struggles into the spheres of common knowledge and above all, justice into passion' is as relevant as ever, but will not be advanced by the machine of 4IR (Ngugi 2005: 105-6). As Ziauddin Sardar warns:

wisdom may not be an attribute that could be transferred to a machine - however 'intelligent' it may be. It is one thing to provide selected traits of wisdom to AI and quite another for AI to actually act wisely. And if we are teaching wisdom to AI, exactly what kind of wisdom is being imparted? .... Wisdom cannot be simply reduced to a set of rules. There are certain key aspects of wisdom - often absent from the discourse that focuses solely on rules and logical components that are specifically human: empathy, compassion, love, forgiveness, sincerity, humility, patience, gratitude, courage, modesty, introspection, contemplation - the old fashioned, time-honored, virtues so essential for acting wisely but so demanding to teach a machine. The very virtues we need to navigate postnormal times ... (2020: 9).

\section{Confronting Wickedness}

All ideas technological and scientific-

Have they all been richly realised

Fully minded and made to serve

And enoble and feed humankind?...

Look at history and see what you find (Okri 1999: 27). 
Timothy Mitchell's book, The Rule of Experts takes us to Egypt in 1942 and shows how in the battle between the Germans and Allies at AlAlamein, some 50,000 to 70,000 Allies were killed. Mitchell relates that in the same year, another 'non-human' force invaded Egypt. This second invader was Anopheles Gambiae, a mosquito. Its' invasion resulted in many more fatalities than the War. Estimates suggested that 750,000 people might have contracted the disease over three years and between 100,000 and 200,000 people died. Despite this incredible loss of life, the mosquito has been written out of history, because 'it cannot speak' (Mitchell 2002: 50).

Mitchell cajoles us to think beyond the human world to the nonhuman, viruses, and insects as agents of history trespassing borders, both geographic and disciplinary:

The connections between a war, an epidemic, and a famine depended upon connections between rivers, dams, fertilizers, food webs .... What seems remarkable is the way the properties of these various elements interacted .... But there are no accounts that take seriously how these elements interact. It is as if the elements are somehow incommensurable .... Each of these processes and forces has its own science, which identifies the agents, time lines, geo-spatial scales, and modes of interaction appropriate to its analysis. This tends to leave each of them isolated in their separate sciences. The isolation may be appropriate for the task of a particular science or technical expertise, but its limitations are striking .... Since those interactions belong ... to some of the most profound transformations of the modern era, this presents a problem for social science. Instead of developing the kinds of analysis that might address these interactions, responding to the techno-scientific transformations of the twentieth century, social theory is still largely trapped in the methods and divisions of labour of the nineteenth century (2002: 27-28).

In 2020, the challenges posed by COVID-19 force us to develop methodologies that go beyond the separation of the sciences into natural and social and to encourage ways of thinking that 'address interactions'.

One of the dangers is that as universities grapple with new ways and forms of teaching, research could be seen as what 'other people do', reducing us to consumers and disseminators of knowledge, not its originators. But, what 


\section{Ashwin Desai}

has been referred to as 'discovery' research must remain as one of the core goals of universities; original research that gets fed back into classrooms and into society at large. How to place research alongside teaching in importance is a challenge. The League of European Research Universities neatly sums up this relationship:

Basic research ... creates the new knowledge that is the ultimate source of most innovation in the economy, society and culture; and provides a framework for an education through which the scepticism, creativity and high-level capability that society needs are embodied in people. Research-intensive universities that couple world class research and education provide the most efficient means of providing this combination of basic research and research-based education. Research universities uniquely have the disciplinary breadth perennially to reconfigure their research efforts to address research needs and opportunities. Basic research should flourish alongside strategic and applied research and professional practice (cited in Taylor 2006: 3).

One gets the sense that, while there will be a blend of online and classroom lectures; a hybrid model of a university will emerge. My university is built in the form of a laager that 'protected' whites and prevented Black students from entering. The racial laager has long been breached and thousands of Black students now stream in every day. Still a laager, but a non-racial one. With online learning, the university is breaking out. Accessibility will be increased as layers of students can register, with the flexibility of periodically returning to study and not having to give up their jobs or re-training themselves to get one. Rather than captive of a once off degree that was attained twenty years before, whose curriculum was already twenty years old, the possibility exists of re-tooling and re-skilling. Collini's point for these times is apposite:

We need to be able to articulate an understanding of what universities are for that is adequate to our time if we are to be able to decide what to do. This does not mean being committed to resisting change or to clinging to how things were done the day before yesterday, still less to denying the fundamental forces in the world that are bound to affect the character and functioning of universities. Quite the contrary, in fact. If things were not changing so quickly, we might manage to 
hobble along leaving our working assumptions implicit, not needing to be exposed, scrutinized and developed. But we're most emphatically not in that position. We simply have to talk about these general matters because the changes we are experiencing are so extensive and so fundamental that we cannot any longer feel confident that we have any working assumptions that are widely agreed (Collini 2017: 17-16).

We are entering an uneasy period of old and new in which we need to think through the paths we follow. The academy is replete with those simply hoping to escape the currents of the time, defending their 'academic freedom', demanding to be left alone or simply continuing like automatons to drift with the currents. In this pivotal moment, confronted with 'wicked problems', not to respond creatively or simply hare ahead, publish more, graduate more speedily, hoping to outrun the virus of our times, will risk us suffering the fate of Aeschylus, who met his end when an eagle dropped a tortoise on him, thinking his bald head was a stone (Critchley 2009). It bears remembering that Aeschylus is known as the father of tragedy.

\section{References}

Agamben, G. 2020. Requiem for the Students. Dean, A. (trans.). Diario della Crisi, 23 May. Available at:

https://www.iisf.it/index.php/attivita/pubblicazioni-e-archivi/diariodella-crisi/giorgio-agamben-requiem-per-gli-studenti.html

(Accessed on 29 May 2020).

Atrey, S. 2020. Universities Beware: Shifting Courses Online so Quickly is a Double-Edged Sword. The Guardian 20 May. Available at:

https://www.theguardian.com/education/2020/may/20/universitiesbeware-shifting-classes-online-so-quickly-is-a-double-edged-sword (Accessed on 21 May 2020).

Baum, S. \& M. McPherson. 2019. The Human Factor: The Promise and Limits of Online Education. Daedalus, Journal of American Academy of Arts \& Sciences 148,4: 235 - 254.

https://doi.org/10.1162/daed_a_01769

Black, S. 2020. The Problem with Stephen Grootes' Views about Online Learning. The Daily Maverick, 11 May. Available at: 
https://www.dailymaverick.co.za/opinionista/2020-05-11-the-problemwith-stephen-grootes-views-about-online-learning/

(Accessed on 18 May 2020).

Bonk, C. 2009. The World is Open: How Web Technology Is Revolutionizing Education. San Francisco: Jossey-Bass.

Brown, V., J. Harris \& J. Russell (eds.). 2010. Tackling Wicked Problems.

London: Earthscan. https://doi.org/10.4324/9781849776530

Bunders, J., A. Bunders \& M. Zweekhorst 2015. Challenges for Interdisciplinary Research. In Werlen, B. (ed.): Global Sustainability.

Switzerland: Springer. https://doi.org/10.1007/978-3-319-16477-9_2

Clapham, C. 2020. Decolonising African Studies. Journal of Modern African

Studies 58,1: 137 - 153. https://doi.org/10.1017/S0022278X19000612

Collini, S. 2017. Speaking of Universities. London: Verso.

Comins, L. 2020. Varsity Group Challenge Online Option: Academics, Students say Poor Students Without Resources Will be Left Behind. The Mercury 12 May. Available at:

https://www.iol.co.za/mercury/news/academics-students-say-poor-

students-without-resources-will-be-left-behind-47839202 (Accessed on 13 May 2020.)

Connor, S. 2019. The Madness of Knowledge: On Wisdom, Ignorance and Fantasies of Knowing. London: Reakton Books.

Critchley, S. 2009. The Book of Dead Philosophers. London: Granta Publications.

Davey, M. 2020. Unreliable Data: How Doubt Snowballed over COVID-19

Drug Research that Swept the World. The Guardian 4 June. Available at: https://www.theguardian.com/world/2020/jun/04/unreliable-data-doubtsnowballed-covid-19-drug-research-surgisphere-coronavirus-

hydroxychloroquine (Accessed on 5 June 2020).

Dyer, G. 1997. Out of Sheer Rage. New York: North Point Press.

Freeman, R. 1976. The Overeducated American. New York: Academic Press. Harari. Y. 2018. 21 Lessons for the 21st Century. London: Jonathan Cape.

Illich. I. 1973. After Deschooling, What? In Gartner, A., C. Greer \& F. Reissman (eds.): After Deschooling, What? New York: Harper \& Row. Ivancheva, M. \& R. Swartz. 2020. Universities go Online during the Pandemic: Who Reaps the Profits? Coronatimes 1 May. Available at: https://www.coronatimes.net/universities-go-online-pandemic-profits/ (Accessed on 2 May 2020). 
Kelly, S. \& M. Enserink. 2020. The Pandemic's First Major Research Scandal Erupts. Science 368,6495: 1041 - 1042.

https://doi.org/10.1126/science.368.6495.1041

PMid:32499418

Kuper, S. 2020. How the Pandemic is Sending Universities Back to School.

Financial Times 14 May. Available at:

https://www.ft.com/content/554ff744-93fe-11ea-abcd-371e24b679ed

(Accessed on 18 May 2020).

Laszlo, E. 2005. Vision 2020: Reordering Chaos for Global Survival. Reading:

Taylor and Francis.

Lingua Franca (eds.). 2000. The Sokal Hoax: The Sham That Shook the Academy. Lincoln, NE: University of Nebraska Press.

Mayer-Schonberger, V. \& K. Cukier. 2013. Big Data: A Revolution that Will

Change the Way We Live, Work, and Think. New York: HoughtonMifflin.

Mitchell, T. 2002. Rule of Experts: Egypt, Techno-Politics, Modernity. Berkeley: University of California Press.

https://doi.org/10.1525/9780520928251

Mohman, K., W. Ma \& D. Baker 2008. The Research University in Transition:

The Emerging Global Model. Higher Education Policy 21,1: 5 27. Available at:

https://doi.org/10.1057/palgrave.hep.8300175 (Accessed on 29 May 2020).

Moosa, F. 2020. Students Speak Out about their Online Learning Experiences.

The Daily Vox 27 May. Available at:

https://www.thedailyvox.co.za/students-speak-about-their-online-

learning-

experiences/?ct=t(EMAIL_CAMPAIGN_3_24_2020_15_6_COPY_01) (Accessed on 29 May 2020).

Mounk, Y. 2018. What an Audacious Hoax Reveals About Academia. The Atlantic 5 October. Available at:

https://www.theatlantic.com/ideas/archive/2018/10/new-sokalhoax/572212/ (Accessed on 4 May 2020.)

Mzileni, P. 2020. How COVID-19 will Affect Students. Mail \& Guardian 23

April. Available at: https://mg.co.za/education/2020-04-23-how-covid19-will-affect-students/ (Accessed on 18 May 2020.)

Ngugi, W. 2005. Decolonising the Mind. Suffolk: James Currey. 
Nicholls, C. 1997. Journeys. London: J.M. Dent.

Noble, D.D. 1998. The Regime of Technology in Education. In Beyer, L.E. \& M.W. Apple (eds.): The Curriculum: Problems, Politics, and Possibilities. $2^{\text {nd }}$ Edition. Albany, NY: State University of New York Press.

Nzimande, B. 2020. Minister Blade Nzimande: Measures to Phase out the Coronavirus COVID-19 Lockdown and Phasing in of PSET Strategic Functions. Available at: https://www.gov.za/speeches/minister-bladenzimande-measures-phase-out-coronavirus-covid-19-lockdown-andphasing-pset (Accessed 18 May 2020.)

Okri, B. 1999. Mental Fight. London: Phoenix House.

Pomerantsev, P. 2019. The Disinformation Age: A Revolution in Propaganda. The Guardian Review 27 July. Available at:

https://www.theguardian.com/books/2019/jul/27/the-disinformation-agea-revolution-in-propaganda (Accessed on 1 May 2020.)

Rees, J. 2018. Is it a Bird? Is it a Plane? No, It's SUPERPROFESSOR!!! The Sociological Review 4 December. Available at:

https://www.thesociologicalreview.com/is-it-a-bird-is-it-a-plane-no-itssuperprofessor/ (Accessed on 19 May 2020.)

Reiersgord, D. 2020. Online Education During the Pandemic: The Challenges and Opportunities. Daily Maverick 3 April. Available at:

https://www.dailymaverick.co.za/article/2020-04-03-online-educationduring-the-pandemic-the-challenges-and-opportunities/ (Accessed on 19 May 2020.)

Rhoads, R., J. Berdan \& B. Toven-Lindsey 2013. The Open Courseware Movement in Higher Education: Unmasking Power and Raising Questions about the Movement's Democratic Potential. Educational Theory 63,1: 87 - 109. https://doi.org/10.1111/edth.12011

Rosa, H. 2010. Alienation and Acceleration: Towards a Critical Theory of Late-Modern Temporality. Malmo: NSU Press.

Roth, G. 2019. The Educated Underclass: Students and the Promise of Social Mobility. London: Pluto Press. https://doi.org/10.2307/j.ctvfp63kb

Sardar, Z. 2020. The Smog of Ignorance: Knowledge and Wisdom in Postnormal Times. Futures 120: 1 - 12.

https://doi.org/10.1016/j.futures.2020.102554

Shay, S. 2020. Online Remote Teaching in Higher Education is not the Problem. The Daily Maverick 3 May. Available at: 
https://www.dailymaverick.co.za/article/2020-05-03-online-remoteteaching-in-higher-education-is-not-the-problem/ (Accessed on 18 May 2020.)

Smyth, J. 2017. The Toxic University. Zombie Leadership, Academic Rock Stars and Neoliberal Ideology. London: Palgrave Macmillan.

https://doi.org/10.1057/978-1-137-54968-6

Taylor, J. 2006. Managing the Unmanageable. The Management of Research in Research-Intensive Universities. Higher Education Management and Policy 18,2: 1 - 25. https://doi.org/10.1787/hemp-v18-art8-en

Taylor, M.C. 2014. Speed Limits: Where Time Went and Why we Have so Little Left. New Haven, CT: Yale University Press.

Universities with a Public Conscience 2020. A Proposed Plan for a Social Pedagogy Alternative in the Time of Pandemic. Drafted through a National Discussion in South Africa amongst Concerned Academics, April 2020.

Urry, J. 2016. What is the Future? Cambridge: Polity.

Wright-Mills, C. 1959/2000. The Sociological Imagination. Oxford: Oxford University Press.

Ashwin Desai

Professor

Department of Sociology University of Johannesburg ashdesai1@gmail.com 